\title{
Histopathological pattern of ovarian neoplasms in Sub-Himalayan belt of rural India: a four-year study from a tertiary care teaching hospital
}

\author{
Manupriya Sharma $^{1 *}$, Anjali Soni ${ }^{2}$, Rashmi Kaul $^{1}$
}

\begin{abstract}
${ }^{1}$ Department of Pathology, Dr. Rajendra Prasad Government Medical College, Kangra, Himachal Pradesh, India ${ }^{2}$ Department of Obstetrics and Gynecology, Dr. Rajendra Prasad Government Medical College, Kangra, Himachal Pradesh, India
\end{abstract}

Received: 22 September 2017

Accepted: 27 October 2017

\author{
*Correspondence: \\ Dr. Manupriya Sharma, \\ E-mail: manupriya.priyasharma@gmail.com
}

Copyright: (C) the author(s), publisher and licensee Medip Academy. This is an open-access article distributed under the terms of the Creative Commons Attribution Non-Commercial License, which permits unrestricted non-commercial use, distribution, and reproduction in any medium, provided the original work is properly cited.

\begin{abstract}
Background: Ovarian tumors are one of the ubiquitous and common forms of neoplasms in women. The aim of the study was to understand the pattern of benign and malignant ovarian neoplasms and their distribution in different age groups in rural population of India.

Methods: A retrospective study conducted in the Department of Pathology in close collaboration with Department of Obstetrics and Gynecology, Dr. Rajendra Prasad Government Medical College, Kangra at Tanda (HP), India. All the patients irrespective of age group who were operated for ovarian neoplasms (benign or malignant) were included in this retrospective analysis over duration of four years (2013 to 2016). "WHO classification system" was used, for classification of all these ovarian tumors. The incidence of these tumors with respect to age group was also studied.

Results: During the study period (2013-2016), there were a total of 242 surgeries for ovarian neoplasms. Of these, majority of the tumours were benign $184(76 \%)$, but an alarming number of women had malignant ovarian tumours $51(21 \%)$, remaining $7(3 \%)$ cases were borderline. Age wise distribution was 7\% (16/242) in less than 20 years age, $19 \%$ (46/242) in 20-30 years age, 29\% (69/242) in 30-40 years age group, 24\% (59/242) in 40-50 years and remaining $21 \%(52 / 242)$ in more than 50 years age group. Pre-dominantly benign tumors were surface epithelial tumors (serous/ mucinous cystadenoma), germ cell tumors (mature cystic teratoma) and endometrioma. Major malignant tumors were surface epithelial tumors (serous/mucinous cystadeno-carcinoma), and germ cell tumors (dysgerminoma, immature teratoma).

Conclusions: In this sub-Himalayan belt of rural India, the incidence of benign ovarian tumors was $76 \%$. Borderline ovarian tumors were seen in $3 \%$ cases and the remaining $21 \%$ cases were malignant ones. Even though benign tumors were the commonest for each age group, however as the age of women increased the proportion of malignant tumors in them increased. Surface epithelial tumors are the most common class of tumors in both benign and malignant tumors. Serous cystadenoma is the most common ovarian tumor overall as well as most common benign tumor whereas serous cystadeno-carcinoma is most common malignancy. Stromal ovarian tumor (one case) is a rarity. Only one woman had bilateral ovarian tumor.
\end{abstract}

Keywords: Benign, Borderline, Incidence, Malignant, Ovarian tumors, Rural India, Surface epithelial tumors

\section{INTRODUCTION}

Ovarian tumors are one of the ubiquitous and common forms of neoplasms in women. Of all the female genital malignancies, ovarian tumors constitute $30.0 \% .^{1}$ Especially due to lack of any reasonable screening test for detection of ovarian malignancy, Asian countries have an estimated incidence of 26 new cases per 1,00,000 
women per year. ${ }^{2}$ Ovarian carcinoma is the fourth most common female cancer and the fourth leading cause of death among cancer deaths in female. ${ }^{3-5}$

Ovarian tumors are notorious in a way as they escape attention in early stage due to relatively larger space available in pelvis and abdominal cavity for expansion. They only come to attention when they have achieved huge size. Definite diagnosis of these tumors, require histopathology confirmation. So usually surgery is mainstay of treatment wherein after excision of the tumor diagnosis is possible. Final treatment and prognosis of these women depends upon histo-pathological diagnosis.

In rural India especially Sub-himalayan belt, there is dearth of data with respect to incidence and nature of ovarian lesions seen. With focus of the government on maternal and child health services, these women take a back seat and are usually neglected. Social and economic reasons also play a major role in health seeking behavior of these women. ${ }^{6}$

Hence, this study was done so as to have some baseline data that might help in estimating the problem load and planning and management of health strategies for these women.

\section{METHODS}

This retrospective study was conducted by the department of Pathology in close collaboration with the department of OBG, in Dr Rajendra Prasad Government Medical College, Kangra at Tanda (HP). This is a tertiary care teaching hospital catering to adjoining rural and tribal population of around 6 lakhs of population. Annually there are around 8000-10,000 deliveries.

All the women who were operated in the Department of OBG with respect from January 2013 to December 2016 were enrolled in this study. The data was collected from the requisition forms of these women accompanying the specimen. The final diagnosis was confirmed after the histo-pathological evaluation. Subsequently, all the women who were operated for the ovarian tumors were enrolled. Wherever required the original case sheets of the women were also reviewed.

During the study period, the incidence of ovarian tumors was estimated. Overall the tumors were classified as per WHO classification system into benign, malignant and borderline tumors. Furthermore, the subtyping of the pathology was done as per final histo-pathological type of the tumor.

The age distribution of these women with ovarian tumors was considered with groups; less than 20 years, 20-30 years, 30-40 years, 40-50 years and >50 years. After tabulation data, the most common benign and malignant tumors were further segregated as per already defined age groups. The ovarian tumors were stratified as most common and commonly encountered tumors in both benign and malignant groups. Bilaterality of these tumors was also observed. Most common tumors encountered in younger age group i.e. less than 20 years and elderly age group i.e. more than 50 years of age were also assessed and stratified as per our population.

\section{RESULTS}

During the study period (2013-2016), there were a total of 242 gynaecological surgeries for ovarian tumors. Out of all these tumors, $184(76 \%)$ were benign, 7 (3\%) were borderline and $51(21 \%)$ were malignant.

Of all the tumors only one was bilateral (serous cystadeno-carcinoma). There were two cases of torsion ovarian tumors who presented in emergency (both benign).

As shown in Table 1, the distribution of ovarian tumors with respect to age was; less than 20 years of age cases $16(7 \%)$, in age group of $20-30$ years there were 46 cases (19\%), in age group 30-40 years there were 69 cases (29\%), in 40-50 age group $59(24 \%)$, and in more than 50 years age group there were 52 (21\% cases).

Table 1: Distribution of ovarian tumors as per age and histopathology.

\begin{tabular}{|c|c|c|}
\hline Age & $\begin{array}{l}\text { Total number of } \\
\text { tumors } \\
(\mathrm{n}=242)\end{array}$ & $\begin{array}{l}\text { Nature } \\
\text { (benign/borderline/ } \\
\text { malignant) (n) }\end{array}$ \\
\hline \multirow{3}{*}{$<20$} & \multirow{3}{*}{$16(7 \%)$} & Benign: 14 \\
\hline & & Borderline: nil \\
\hline & & Malignant: 02 \\
\hline \multirow{3}{*}{$20-30$} & \multirow{3}{*}{$46(19 \%)$} & Benign: 42 \\
\hline & & Borderline: nil \\
\hline & & Malignant: 04 \\
\hline \multirow{3}{*}{$30-40$} & \multirow{3}{*}{$69(29 \%)$} & Benign: 54 \\
\hline & & Borderline: 02 \\
\hline & & Malignant: 13 \\
\hline \multirow{3}{*}{$40-50$} & \multirow{3}{*}{$59(24 \%)$} & Benign: 35 \\
\hline & & Borderline: 03 \\
\hline & & Malignant: 21 \\
\hline \multirow{3}{*}{$>50$} & \multirow{3}{*}{$52(21 \%)$} & Benign: 39 \\
\hline & & Borderline: 02 \\
\hline & & Malignant: 11 \\
\hline
\end{tabular}

\section{Benign ovarian tumors}

Benign ovarian tumors were the most common tumors in all age groups. As shown in Table 2, less than 20 years of age there were 14 benign tumors $(7 \%)$, in age group of 20 -30 years there were 42 cases $(23 \%)$, in age group 30 40 years there were 54 cases $(30 \%)$, in $40-50$ age group $35(19 \%)$, and in more than 50 years age group there were 39 (21\% cases), as shown in Table 2. 
Table 2: Age wise distribution of benign ovarian tumors.

\begin{tabular}{|c|c|c|c|c|c|}
\hline & $<20$ & 20-30 & $30-40$ & $40-50$ & $>50$ \\
\hline \multicolumn{6}{|c|}{ Surface epithelial tumors } \\
\hline Serous cystadenoma & 4 & 6 & 15 & 8 & 19 \\
\hline Mucinous cystadenoma & 3 & 10 & 8 & 9 & 10 \\
\hline Brenners tumor & - & - & - & 1 & - \\
\hline \multicolumn{6}{|l|}{ Germ cell tumors } \\
\hline Mature cystic teratoma & 3 & 17 & 13 & 8 & 5 \\
\hline Endometrioma & 3 & 7 & 14 & 5 & 1 \\
\hline Fibroma/thecoma & - & - & 2 & 2 & - \\
\hline \multicolumn{6}{|l|}{ Others } \\
\hline $\begin{array}{l}\text { Corpus luteal } \\
\text { hematoma }\end{array}$ & - & - & 1 & 1 & - \\
\hline Adeno-fibroma & - & - & 1 & - & 2 \\
\hline Simple cyst & - & 1 & - & - & - \\
\hline Torsion & 1 & - & - & - & 1 \\
\hline $\begin{array}{l}\text { Hyper reactio- } \\
\text { luteanalis }\end{array}$ & - & 1 & - & - & - \\
\hline $\begin{array}{l}\text { Stromal ovarian } \\
\text { tumor }\end{array}$ & - & - & - & - & 1 \\
\hline Total & 14 & 42 & 54 & 35 & 39 \\
\hline
\end{tabular}

\section{Surface epithelial benign ovarian tumors}

Overall, they constituted $51 \%(93 / 184)$ of all benign tumors. In age group less than 20 years of age there were $7 / 14(50 \%)$ cases, in age group of 20-30 years there were $16 / 42(38 \%)$ cases, in age group 30-40 years there were $23 / 54$ cases $(43 \%)$, in $40-50$ age group $18 / 35(51 \%)$, and in more than 50 years age group there were 29/39 (74\%) cases, as shown in Table 2.

Dermoid cyst (mature cystic teratoma) was seen in $25 \%$ (46/184) of all benign tumors. Its incidence was less than 20 years of age cases $3 / 14(21 \%)$, in age group of 20-30 years there were $17 / 42$ cases $(40 \%)$, in age group 30-40 years there were $13 / 54$ cases $(24 \%)$, in $40-50$ age group $8 / 35(23 \%)$, and in more than 50 years age group there were $5 / 39(13 \%)$ cases, as shown in Table 2 .

\section{Endometrioma}

Overall incidence of endometriomas was $16 \%(30 / 184)$ of all benign tumors. In age group less than 20 years of age there were $3 / 14(21 \%)$ cases, in age group of 20-30 years there were $7 / 42$ cases $(17 \%)$, in age group $30-40$ years there were $14 / 54$ cases (26\%), in 40-50 age group $5 / 35(14 \%)$, and in more than 50 years age group there were $1 / 39(2 \%)$ cases, as shown in Table 2 .

\section{Others}

Other ovarian tumors were 15 cases. These were; fibroma/thecoma 4 cases, adeno-fibroma 3 cases, corpus luteal hematoma 2 cases, torsion ovarian cyst 2 cases, and one case each of Brenner's tumor, hyper reaction luteanalis, simple ovarian cyst and stromal ovarian tumor, (shown in Figure 1).

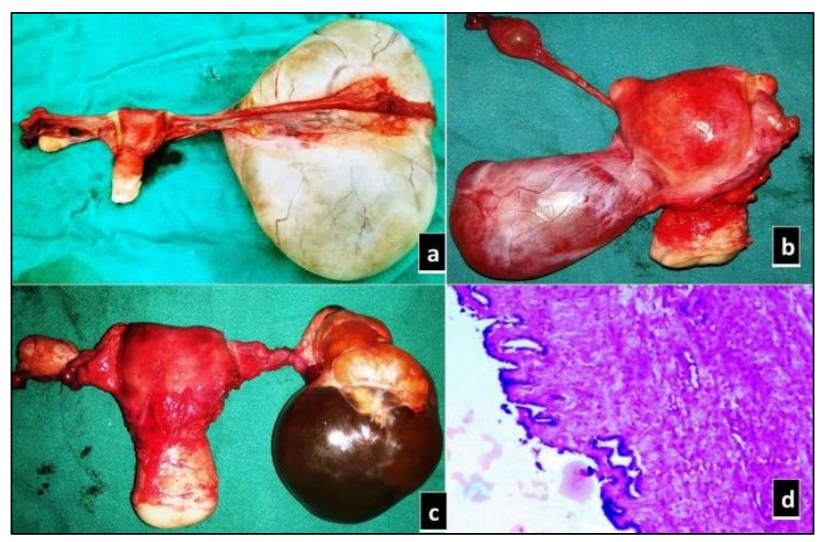

Figure 1: (a) Papillary cystadenoma; (b): Benign inclusion cyst; (c): Endometriosis; (d): Histopathology showing benign papillary cystadenoma.

\section{Borderline ovarian tumors}

Borderline ovarian tumors were seen in 7 cases (3\%) only. There were 2 cases each in age group 30-40 and more than 50 years age. In age group 40-50 there were 3 cases. Overall there were 4 mucinous and 3 serous borderline cystadeno-carcinomas, (shown in Figure 2).

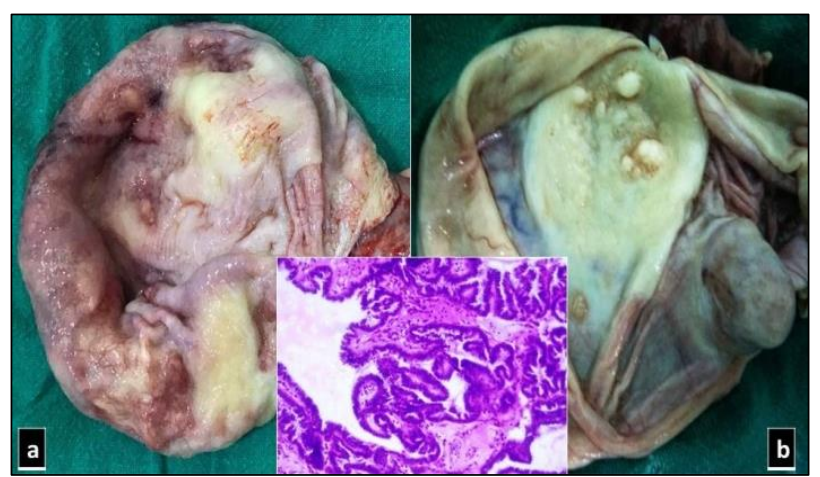

Figure 2: (a) Cut surface of ovarian tumor showing irregular velvety thickening; (b) Cut section of ovarian tumor with mural nodules (inset;

histopathology showing borderline ovarian tumor).

\section{Malignant ovarian tumors}

There was a total of $21 \%(51 / 242)$ women with malignant ovarian carcinomas.

\section{Surface epithelial malignant ovarian tumors}

Of all malignant tumors, there were 38/51 (74\%) surface epithelial malignant ovarian tumors. Of these $28(74 \%)$ were serous and $10(26 \%)$ were mucinous cystadenocarcinomas. Age wise distribution of these surface epithelial ovarian tumors was; in age group less than 20 and 20-30 there was no case, in 30-40 years age group 
there were $9(24 \%)$ case, in $40-50$ years age group there were $18(48 \%)$ cases and in more than 50 years age group there were $10(28 \%)$ cases, as shown in Table 3.

Table 3: Age wise distribution of malignant ovarian tumors.

\begin{tabular}{|lccccc|}
\hline \multicolumn{1}{l}{$\begin{array}{l}<0 \\
\text { Surface epithelial tumors }\end{array}$} & $20-30$ & $30-40$ & $40-50$ & $>50$ \\
\hline $\begin{array}{l}\text { Serous cystadeno- } \\
\text { carcinoma }\end{array}$ & - & - & 7 & 14 & 7 \\
\hline $\begin{array}{l}\text { Mucinous cystadeno- } \\
\text { carcinoma }\end{array}$ & - & - & 2 & 3 & 3 \\
\hline $\begin{array}{l}\text { Endometroid } \\
\text { carcinoma }\end{array}$ & - & - & 1 & 1 & - \\
\hline Clear cell carcinoma & - & - & - & 1 & - \\
\hline $\begin{array}{l}\text { Germ cell tumors } \\
\text { Dysgerminoma }\end{array}$ & 1 & 2 & - & - & - \\
\hline Yolk Sac tumor & - & 1 & 1 & - & - \\
\hline $\begin{array}{l}\text { Immature teratoma } \\
\text { Others }\end{array}$ & 1 & - & - & - & - \\
\hline $\begin{array}{l}\text { Poorly differentiated } \\
\text { tumor }\end{array}$ & - & - & - & - & 1 \\
\hline $\begin{array}{l}\text { Signet ring cell } \\
\text { carcinoma }\end{array}$ & - & - & 1 & 1 & - \\
\hline $\begin{array}{l}\text { Sertoli-Leydig cell } \\
\text { tumors }\end{array}$ & - & - & 1 & - & - \\
\hline $\begin{array}{l}\text { Granulosa cell } \\
\text { tumors }\end{array}$ & - & 1 & - & - & - \\
\hline $\begin{array}{l}\text { Metastatic carcinoma } \\
\text { Total }\end{array}$ & - & - & - & 1 & - \\
\hline
\end{tabular}

\section{Germ cell tumors}

Overall there were $6(12 \%)$ cases of malignant germ cell tumors. There were 3 cases of dysgerminoma, 2 cases of yolk sac tumors and one case of immature teratoma. Age wise distribution of these tumors is shown in Table 3. there were 2 cases in less than 20 years, 3 cases in 20-30 years, one case in 30-40 years and no case in 40-50 years and more than 50 years age group, as shown in Table 3 .

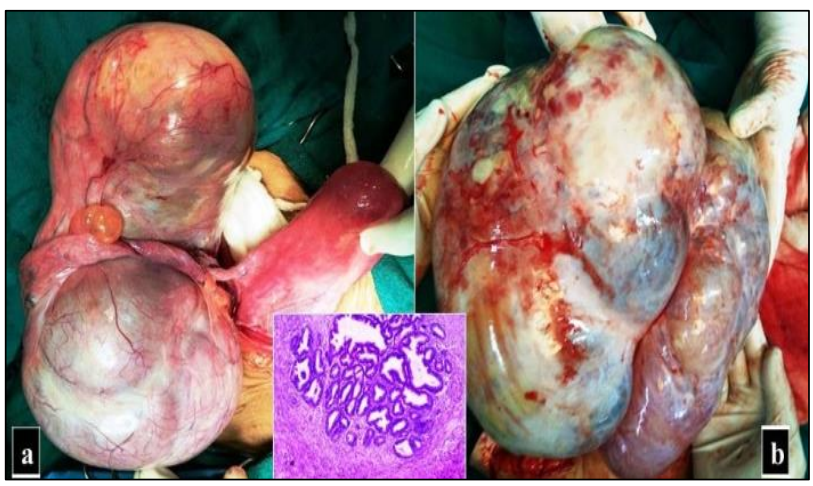

Figure 3: (a) Large malignant ovarian tumor (predominantly solid); (b) Large solid cystic unilateral malignant ovarian tumor (inset: histopathology confirms mucinous cystadeno-carcinoma).

\section{Others}

There were 7 other histo-pathologically examined ovarian tumors. These were signet cell carcinoma (2 cases), there was one case each of sertoli-leydig cell tumor, poorly differentiated tumor, granulosa cell tumor and metastatic carcinoma, (shown in Figure 3).

\section{DISCUSSION}

We observed that of all the women with ovarian tumors, around $21 \%$ had malignant ovarian tumors in subHimalayan belt of rural India. Present observations are in agreement with the estimated incidence in India and abroad. Approximately $20-30 \%$ of all ovarian tumors were malignant as per available literature from India and west. $^{7-9}$

In all the age groups, the benign tumors are more common, however as the age group advances the proportion of women with malignant ovarian tumors increases. One of the most common ovarian tumors for all the age groups was surface epithelial tumors (both benign and malignant tumour). Considering individual tumors, serous cystadenoma is the most common ovarian tumor whereas serous cystadeno-carcinoma is the most common malignancy. Germ cell tumors are common tumors up to 30 years of age with limited cases identified after that. Except for few isolated cases, malignant ovarian tumors are more common above 40 years.

On further distribution with respect to age, three most common benign tumors were; surface epithelial tumors, germ cell tumors (mature cystic teratoma) and endometrioma. Serous cystadenoma is the most common ovarian neoplasm overall as well as in benign tumors. Dermoid cyst or mature cystic teratoma is the second commonest benign ovarian tumor. Despite such a high incidence of ovarian tumors in early age groups (up to 30 years) only two patients were with torsion ovarian tumor and only one of them was in this age group. Endometriomas are also quite common in rural population predominantly in age group 30-40 years possibly due to early marriage and high fertility in rural population. ${ }^{6}$

Malignant tumors observed in our population were predominantly surface epithelial malignant ovarian tumors $(74 \%)$. In age wise distribution, more than 40 years age group comprised $67 \%$ of malignant tumors observed. In early age group i.e. less than 30 years a total of 6 cases were observed and nearly all except one (serous cystadeno-carcinoma) were germ cell tumors. Other histological types were uncommon in our population. Surprisingly there was only case of stromal ovarian tumor. Additionally, of all the tumors only one woman had bilateral ovarian tumor (malignant serous cystadeno-carcinoma). This pattern of ovarian neoplasms is in gross variation with that observed by other researchers both in India and abroad. ${ }^{10-13}$ Hence the need 
of the hour is to have a region wise cancer registry so as to plan health policies according to the need and demand of that particular region.

However, one major limitation of the present study is that it is an institution based study and has small sample size. Nonetheless, due to dearth of data from this particular region regarding genital malignancies we have to rely on these observations even if the results obtained may not reflect the actual histological pattern of ovarian tumors in this region.

\section{CONCLUSION}

We propose that a state wise as well as a national registry of malignancies be maintained so as to have detailed and in-depth knowledge of the genital malignancies in our country which have a totally different pattern than as in the western population. This will go a long way in providing standard treatment of care to these neglected women.

\section{Funding: No funding sources}

Conflict of interest: None declared

Ethical approval: The study was approved by the Institutional Ethics Committee

\section{REFERENCES}

1. Benson RC. Diagnosis and treatment. Current Obstet Gynaecol. 1976;1:236.

2. Murad A. Ovulation induction and ovarian tumor: the debate continues. J Pak Med Assoc. 1998;48:353-6.

3. Sen U, Sankaranarayanan R, Mandal S, Romana AV, Parkin DM, Siddique M. Cancer patterns in Eastern India. The first report of Kolkata Cancer Registy. Int J Cancer. 2002;100:86-91.

4. Tortulero L, Mitchell FM, Rhodes HE. Epidemidology and screening of ovarian cancer. Obstet Gynaecol Clin North Am. 1994;21:63-75.
5. Rashid S, Sarwas G, Ali A. A Clinicopathological study of ovarian cancer. Mother Child. 1998;36:11725.

6. Sharma C, Sharma M, Raina R, Soni A, Chander B, Verma S. Gynecological diseases in rural India: a critical appraisal of indications and route of surgery along with histopathology correlation of 922 women undergoing major gynaecological surgery. J Midlife Health. 2014;5(2):55-61.

7. Goldstein DP, Laufer MR. Benign and malignant ovarian masses. In: Email SJ, Laufer MR, Foldstein DP, eds. Pediatrics and adolescent Gynecology, Philadelphia: Lippincott Raven: 1998.

8. Pilli GS, Suneeta KP, Dhaded AV, Yenni VV. Ovarian tumors: a study of 282 cases. J Indian Med Assoc 2002;100:423-4.

9. Gupta N, Bisht D, Agarwal AK, Sharma VK. Retrospective and prospective study of ovarian tumors and tumor like lesions. Indian $\mathrm{J}$ Pathol Microbiol. 2007;50:525-7.

10. Ahmad Z, Kayani N, Hasan SH, Muzaffar S, Gill MS. Histological pattern of ovarian neoplasm. J Pak Med Assoc. 2000;50:416-9.

11. Gracy R, Chinnama KR, Thagavelu H. Ovarian Neoplasms: a study of 903 cases. J Obst Gynec India. 1972;22:309.

12. Merino MJ, Jaffe G. Age contrast in ovarian pathology. Cancer. 1993;71(2):537-44.

13. Di Bonito L, Patriarca S, Delendi M, Alberico S. Ovarian tumours anatomohistopathological contribution to their interpretation. Eur J Gynaecol Oncol. 1988;9:324-30.

Cite this article as: Sharma M, Soni A, Kaul R. Histopathological pattern of ovarian neoplasms in Sub-Himalayan belt of rural India: a four-year study from a tertiary care teaching hospital. Int J Reprod Contracept Obstet Gynecol 2017;6:5448-52. 